\title{
Effect of alternative housing system and hen genotype on egg quality characteristics
}

\author{
Zofia Sokołowicz $^{1 *}$, Józefa Krawczyk², Magdalena Dykiel ${ }^{3}$ \\ ${ }^{1}$ Department of Animal Production and Poultry Products Evaluation, University of Rzeszów, Rzeszów, Poland, ${ }^{2}$ Department. of Animal Genetic \\ Resources Conservation, National Research Institute of Animal Production, Balice, Poland, ${ }^{3}$ State Higher Vocational School in Krosno, \\ Departament of Food Production and Safety, Rynek 1,38-400 Krosno
}

\section{A B S T R A C T}

\begin{abstract}
The aim of the study was to determine the effect of type of alternative housing system and layer genotype on the quality of table eggs. The investigated eggs came from native Greenleg Partridge hens (Z-11) and Rhode Island Red hens (R-11) covered by the gene-pool protection program, as well as from Hy-line Brown commercial hens from litter barn (LS), free range (FR), and organic systems (OS). Eggs for the study were collected from the hens at 56 wk of age. Egg quality assessment was based on the following values egg traits: weight, shape index, yolk, albumen, and shell percentage in the whole egg; eggshell traits: color intensity, weight, thickness, density, breaking strength, physical features of egg content: albumen height, value of Haugh units, yolk color; presence of meat/blood spots and cholesterol, higher fatty acids, vitamin $A$ and $E$ in egg yolks. In the rearing systems under study, eggs with the highest weight were laid by commercial hens, and the type of alternative rearing system had no significant effect on this trait. Shell colour intensity depends on the breed of hen, whereas the rearing system has no significant effect on this trait. Hen genotype and housing system had an effect on egg shell weight, thickness, and density. The housing system influences the content of MUFA, PUFA, PUFAn-6 and PUFAn-3 as well as PUFA 6/3 in egg yolks. No effect of the housing system on egg yolk cholesterol content was observed.
\end{abstract}

Keywords: Egg quality; Housing system; Layer genotype; Fatty-acids

\section{INTRODUCTION}

In accordance with Council Directive 1999/74/EC, table eggs can be produced under the cage, litter, free-range, and organic systems. Recent years have seen a growing interest in eggs from alternative (litter, free-range, and organic) systems to the cage system. Compulsory marking of egg shells with codes and letters, which indicate the housing system (Commission Regulation (EC) No 589/2008), allows consumers to purchase eggs from the systems they prefer.

Studies in the literature concerning the effect of housing system on egg quality in different types of cages have most often evaluated production in different cage types (Holt et al., 2011; Samiullah and Chousalkar, 2014; Y1lmaz Dicmen et al.,2016) and compared eggs from the cage and free-range systems (Wang et al., 2009; Terčič et al., 2012; Jones and Anderson, 2013; Englmaierová et al.,
2014; Y1lmaz Dicmen et al.,2017). Few studies determined whether eggs from alternative housing systems (litter, free-range, organic) differ in egg shell traits, which are important in commercial handling, and in nutritive value. Because eggs in alternative housing systems are produced using both commercial hybrids and native breeds, it is also justified to determine the effect of hen's genotype on the quality of layer eggs. Ascertaining the impact of the type of alternative breeding system and the layers genotype on eggs quality could be of significance both for producers in their decisions regarding selection of layers, suitable for use in particular alternative breeding systems and the consumers that purchase eggs from any rearing system. Hence, the aim of the study was to compare the effect of type of alternative housing system and layer genotype on the egg quality features such as weight and nutritional value (vitamins $\mathrm{A}$ and $\mathrm{E}$, cholesterol), including the profile of fatty acids in egg yolk.

\footnotetext{
${ }^{*}$ Corresponding author:

Zofia Sokołowicz, Uniwersytet Rzeszowski, Wydział Biologiczno-Rolniczy, Katedra Produkcji Zwierzęcej i Oceny Produktów Drobiarskich; ul. M. Ćwiklińskiej 2, 35-601 Rzeszów, Polska; E-mail: zosokolo@ur.edu.pl
}

Received: 22 February 2018; $\quad$ Accepted: 10 June 2018 


\section{MATERIALS AND METHODS}

\section{Birds and management}

The experiment conducted to achieve the aim of this study involved in total 270 hens, including 90 hens of the native breed Green leg Partridge (Z-11), 90 Rhode Island Red (R-11) hens, included in a conservation program in Poland and 90 commercial hybrids Hy-line Brown. At 16 weeks of age, 30 hens of each breed and 30 commercial hybrids were assigned to the following rearing systems: litter barn (group LS), free-range (group FR) and organic (group OS).

The birds of group LS were housed in a poultry house with windows (window area-to-floor area ratio was 1: 15) in deep litter without access to a run (paddock). Indoor stocking density was 6 hens $/ \mathrm{m}^{2}$. Hens from group FR were housed in a poultry house with windows (window area-tofloor area ratio was 1:15) in deep litter with free access to grass-covered open-air run. Indoor stocking density was 6 hens $/ \mathrm{m}^{2}$, while outdoor stocking density was one laying hen per $4 \mathrm{~m}^{2}$. Group OS hens were housed according to regulations pertinent to organic rearing, i.e. EC Directive 1804/1999 and Regulation of European Economic Community (EEC) Council 2092/91. Hens of this group were housed in a poultry house with windows (window area-to-floor area ratio was 1: 15) in deep litter $\left(6\right.$ hens $\left./ \mathrm{m}^{2}\right)$ with free access to grass-covered open-air run with growing trees, while outdoor stocking density was one laying hen per $5 \mathrm{~m}^{2}$. The light schedule in the house was the same for all groups and comprised $16 \mathrm{~h}$ light and $8 \mathrm{~h}$ dark (16L: 8D). In autumn and winter when natural day was shorter than $16 \mathrm{~h}$ daylight was complemented with artificial light. In each tested rearing system, bars were equipped with round feeders, drinkers and nests. In groups FR and OS feeders and drinkers were available also in the run.

Birds of group LS and FR were fed ad libitum with a concentrate layer feed $(16.08 \%$ protein, $11 \mathrm{MJ})$, and group OS hens (ad libitum) were given organic poultry feed $(16.0 \%$ protein, $11 \mathrm{MJ})$. Layer feeds used in all groups did not contain colour feed additives.

\section{Sampling}

To evaluate quality of eggs from different rearing systems, 30 eggs were randomly sampled from hens of every breed/ line and commercial hybrids housed in each system. Eggs were sampled at 56 weeks of hen age. Eggs were evaluated after $24 \mathrm{~h}$ of refrigerated storage at $8^{\circ} \mathrm{C}$ and $55 \%$ humidity. Egg quality assessment was based on the following values: egg traits: weight (g), shape index (\%), yolk, albumen, and shell percentage in the whole egg; eggshell traits: colour intensity $(\%)$, weight $(\mathrm{g})$, thickness $(\mu \mathrm{m})$, density $\left(\mathrm{mg} / \mathrm{cm}^{2}\right)$, breaking strength $(\mathrm{N})$, physical features of egg content: albumen height $(\mathrm{mm})$, value of Haugh units (HU), yolk colour (scores according to a 15-point DSM scale) and presence of meat and blood spots.

\section{Egg weight}

Egg weight was determined by weighing each individual egg with a digital laboratory balance Navigator model NOB 110 (Ohaus, Sweden) exact to $0.1 \mathrm{~g}$.

\section{Shape index}

Shape index of eggs was determined as a ratio of shortto-long axis which were measured using an electronic caliper MITUTOYO Absolute Digmatic Caliper model CD-15DCX (Japan) exact to $0.01 \mathrm{~mm}$.

\section{Relative weight of egg components}

Percentage contents of egg morphological components (albumen, yolk and shell) were calculated based on their weights measured individually for each egg.

\section{Egg shell traits and interior egg traits}

Eggshell colour, weight, density and thickness, HU value, yolk color according to DSM scale were measured using electronic equipment for egg quality measurements (EQM - Egg Quality Measurements, Technical Services and Supplies, UK).

\section{Eggshell strength}

Eggshell strength $(\mathrm{N})$ was measured using a multipurpose testing system, model BT1-FR1.OTH.D14 with measuring head $100 \mathrm{~N}$ and software testXpert (Zwick/Roell GmbH\&Co.KG, Germany).

\section{Biochemical analysis}

Higher fatty acids in egg yolks were quantified as methyl esters by gas chromatography. The samples were prepared according to Folch et al. (1957) whereby the sample was homogenized in chloroform: methanol in a 2:1 ratio, the solvent was evaporated, and evaporation residue was saponified $(0.5 \mathrm{~N} \mathrm{NaOH}$ in methanol) and esterified $\left(\mathrm{BF}_{3}\right.$ in methanol). The fatty acid methyl esters were extracted in hexane and analysed with a VARIAN 3400 gas chromatograph, using a column filled with acid-modified polyethylene glycol (e.g. ZEBRONZB-WAX 30m), an 8200 $\mathrm{CX}$ autosampler and data processing software.

A gas chromatographic validated method was used for determination of cholesterol in egg yolks (Gąsior and Pietras, 2013). The method involves $\mathrm{KOH}(60 \mathrm{~g} / 100 \mathrm{ml})$ saponification and hexane extraction of the cholesterol. Analysis was performed in isothermal conditions $\left(265^{\circ} \mathrm{C}\right)$ on Shimadzu GC 2010Plus gas chromatograph, on a column (30m, I.D. $=0.25 \mathrm{~mm}$, $\mathrm{df}=0.25 \mu \mathrm{m}$ ) with $5 \%$ phenyl, $95 \%$ dimethylpolysiloxane phase, at helium flow, $1.9 \mathrm{ml} / \mathrm{min}$, and FID detector temperature, $300^{\circ} \mathrm{C}$. Cholesterol standard 5-Cholesten- $3 \alpha-\mathrm{ol}, \mathrm{C}_{27} \mathrm{H}_{46} \mathrm{O}$, for 
chromatography (Sigma-Aldrich, USA,) and internal standard $5 \alpha$-cholestane, $\mathrm{C}_{27} \mathrm{H}_{48},>97 \%$ (Sigma-Aldrich, USA) for quantification was used).

Egg yolks were analysed for vitamin A and E content using an accredited procedure based on Polish standards PN-EN.

\section{Statistical analysis}

Statistical analysis of the obtained results was performed using Statistica 12 PL software package. The obtained results were subjected to multi-factor ANOVA (housing system, genotype), and main effects ( $\mathrm{S}$ - effect of housing system, $G$ - effect of genotype, and interactions between factors $(S \times G)$ were determined. Differences were considered to be significant when $\mathrm{P}<0.05$ and highly significant when $\mathrm{P}<0.01$.

Statistical analysis of the obtained results was performed using Statistica 12 PL software package. The effect of housing system, breed and age of layers on the number of eggs with meat and blood spots in egg content was verified with Kruskal-Wallis non-parametric test, and the frequency of meat and blood spots was expressed as percent. The results for the effect of housing system and breed layers on the other egg quality traits was subjected to two-factor analysis of variance and determinations were made of the major effects ( $\mathrm{S}$ - effect of housing system, $\mathrm{G}$ - effect of genotype) and of the effect of the interaction of treatments $(S \times G)$. Significant differences between means in the groups was estimated with Duncan's multiple range test. Differences were considered to be significant when $\mathrm{P}<0.05$ and highly significant when $\mathrm{P}<0.01$.

\section{RESULTS AND DISCUSSION}

The present study showed that the housing system has no effect on hen's egg weight at 56 wk of age (Table 1). In each housing system, commercial hens (Hy-line Brown) produced heavier eggs than hens of the other breeds $(\mathrm{P}<0.01)$. The results obtained correspond with the findings of other authors who reported the types of alternative housing system to have no effect on egg weight (Kühn et al., 2014; Lordelo et al., 2017). The higher weight of eggs from the commercial hens (Hy-line Brown) is probably due to selection for increased laying performance and egg weight in layer flocks, whereas Z-11 and R-11 hens are kept, in line with the genetic resources conservation program, in small populations not selected for productive traits. The influence of genotype on the weight of eggs from organic farms was also confirmed in studies by Hammershøj and Steenfeldt (2015).

Hen's genotype and housing system were found to have an effect on the egg shape index $(\mathrm{P}<0.05)$. Barn eggs were characterized by a higher shape index compared to free-range and organic eggs. Also Dalle Zotte et al. (2013) showed the effect of housing system on egg shape index, but like in our study, they reported no differences in shape index between free-range and organic eggs.

Our study showed no effect of the housing system on shell colour intensity $(\mathrm{P}>0.05)$, which corroborates studies by Lordelo et al. (2017), but this trait was significantly influenced by genotype $(\mathrm{P}<0.05)$ (Table 2$)$, as confirmed by the studies of Krawczyk (2009) and Nedup and Phurba (2014).

The housing system had an influence on egg shell weight, thickness, density and strength $(\mathrm{P}<0.05)$. Breed had an effect on all analysed traits except for shell strength (Table 2).

Scientific papers show inconsistent results regarding the effect of the housing system on egg shell quality. Pavlovski et al. (2001), like in our study, observed thicker shells in barn eggs and thinner shells in free-range eggs. In studies on the quality of organic as well as barn and cage eggs, Ferrante et al. (2009) and Dalle Zotte et al. (2013) found an effect of the rearing system on egg shell thickness. Kühn et al. (2014) concluded that the housing system has no effect on the shell weight and thickness of eggs from the litter floor and free-range systems. Mertens et al. (2006), who investigated the effect of the housing system (cages, aviaries, free range) on egg quality, found shell strength to be the highest for aviary eggs and the lowest for free-range eggs. However, both Yllmaz Dicmen et al.(2017) and Hidalgo et al. (2008)

Table 1: Effect of housing system and hen's genotype on egg weight and shape

\begin{tabular}{|c|c|c|c|c|c|c|c|c|}
\hline \multirow[t]{2}{*}{ Item } & \multirow[t]{2}{*}{ Housing system } & \multicolumn{3}{|c|}{ Genotype } & \multirow[t]{2}{*}{ SEM } & \multicolumn{3}{|c|}{ Effect } \\
\hline & & $\mathrm{Z}-11$ & R-11 & Hy-line Brown & & G & $\mathrm{s}$ & GxS \\
\hline \multirow[t]{3}{*}{ Egg weight (g) } & Litter floor & $56.58^{\mathrm{aA}}$ & $60.38^{\mathrm{bB}}$ & $62.17^{\mathrm{bB}}$ & 0.34 & * & NS & NS \\
\hline & Free range & $56.61^{\mathrm{aA}}$ & $59.67^{\mathrm{bAB}}$ & $60.98^{\mathrm{bB}}$ & & & & \\
\hline & Organic & $57.42^{\mathrm{aA}}$ & $60.98^{\mathrm{abAB}}$ & $62.93^{\mathrm{bB}}$ & & & & \\
\hline \multirow[t]{3}{*}{ Shape index (\%) } & Litter floor & $75.24^{a}$ & $76.86^{b}$ & $76.91^{b}$ & 0.24 & * & * & NS \\
\hline & Free range & $73.13^{\mathrm{aA}}$ & $74.74^{\mathrm{abAB}}$ & $76.10^{\mathrm{bB}}$ & & & & \\
\hline & Organic & 73.15 & 75.52 & 74.97 & & & & \\
\hline
\end{tabular}

G - Genotyp S - Housing system, * significant $(P<0.05)$; NS non significant $(P>0.05)$; $a, b, c-$ values in rows with different letters differ significantly ( $<<0.05)$; $A, B, C$ - values in rows with different letters differ significantly $(P<0.01) ; x, y, z$ - values in columns with different letters differ significantly $(P<0.05) ; X, Y$,

$Z$ - values in columns with different letters differ significantly $(P<0.01)$ 
Table 2: Effect of housing system and hen's genotype on egg shell traits

\begin{tabular}{|c|c|c|c|c|c|c|c|c|}
\hline \multirow[t]{2}{*}{ Item } & \multirow[t]{2}{*}{ Housing system } & \multicolumn{3}{|c|}{ Genotype } & \multirow[t]{2}{*}{ SEM } & \multicolumn{3}{|c|}{ Effect } \\
\hline & & $\mathrm{Z}-11$ & R-11 & Hy-line Brown & & G & $\mathrm{s}$ & GxS \\
\hline \multirow[t]{3}{*}{ Shell colour (\%) } & Litter floor & $68.60^{\mathrm{aA}}$ & $45.15^{\mathrm{bB}}$ & $32.95^{\mathrm{cC}}$ & 1.07 & * & NS & NS \\
\hline & Free range & $68.90^{\mathrm{aA}}$ & $46.07^{\mathrm{bB}}$ & $34.47^{\circ \mathrm{C}}$ & & & & \\
\hline & Organic & $68.90^{\mathrm{aA}}$ & $47.80^{\mathrm{bB}}$ & $32.73^{\mathrm{cC}}$ & & & & \\
\hline \multirow[t]{3}{*}{ Shell weight (g) } & Litter floor & $6.06^{\mathrm{aA}}$ & ${ }^{x} 6.45^{\mathrm{aA}}$ & ${ }^{x \times} 7.72^{\mathrm{bB}}$ & 0.07 & * & * & * \\
\hline & Free range & $6.14^{\mathrm{aA}}$ & ${ }^{\mathrm{y}} 7.24^{\mathrm{bB}}$ & ${ }^{\mathrm{yY}} 7.07^{\mathrm{bB}}$ & & & & \\
\hline & Organic & $6.11^{\mathrm{aA}}$ & ${ }^{\mathrm{z}} 7.79^{\mathrm{bB}}$ & xXY $7.54^{\mathrm{bB}}$ & & & & \\
\hline \multirow[t]{3}{*}{ Shell thickness $(\mu \mathrm{m})$} & Litter floor & $\times \times 351.60$ & xx339.30 & $\times \times 351.93$ & 2.68 & * & * & * \\
\hline & Free range & ${ }^{x \times} 350.75^{\mathrm{aA}}$ & ${ }^{\mathrm{y}} 303.43^{\mathrm{bB}}$ & ${ }^{\mathrm{y}} 320.70^{\mathrm{bB}}$ & & & & \\
\hline & Organic & ${ }^{y} 325.60$ & x×333.00 & ${ }^{\mathrm{y}} 318.00$ & & & & \\
\hline \multirow[t]{3}{*}{ Shell density $\left(\mathrm{mg} / \mathrm{cm}^{2}\right)$} & Litter floor & $80.38^{\mathrm{aA}}$ & $\times \times 73.17^{\mathrm{bA}}$ & ${ }^{x x} 100.14^{c B}$ & 1.06 & * & * & * \\
\hline & Free range & $76.59^{\mathrm{aA}}$ & ${ }^{\mathrm{yY}} 100.26^{\mathrm{bB}}$ & ${ }^{x \times} 102.53^{b B}$ & & & & \\
\hline & Organic & $81.64^{\mathrm{aA}}$ & ${ }^{\mathrm{yY}} 101.67^{\mathrm{bB}}$ & yY $90.49^{\mathrm{cA}}$ & & & & \\
\hline \multirow[t]{3}{*}{ Shell strength $(\mathrm{N})$} & Litter floor & 31.85 & 32.67 & ${ }^{x \times} 35.90$ & 0.46 & NS & * & NS \\
\hline & Free range & 31.75 & 31.54 & ${ }^{\mathrm{y} Y} 31.37$ & & & & \\
\hline & Organic & 29.32 & 31.13 & ${ }^{y \curlyvee} 30.73$ & & & & \\
\hline
\end{tabular}

G - Genotyp S - Housing system, * significant $(P<0.05)$; NS non significant $(P>0.05)$; $a, b, c-$ values in rows with different letters differ significantly $(P<0.05)$; $A, B, C$ - values in rows with different letters differ significantly $(P<0.01) ; x, y, z$ - values in columns with different letters differ significantly $(P<0.05) ; X, Y$,

$Z$ - values in columns with different letters differ significantly $(P<0.01)$

showed no differences in shell strength between eggs from different housing systems. Studies conducted by Samiullah et al. (2017) did not indicate any differences either in shell weight, thickness or the percentage of shell content of eggs from hens held in barns or free-range. Similar lack of differences in percentage of shell content of eggs from litter floor, free-range and organic farming systems were posted by Lordelo et al. (2017).

In our study, breed was found to have an effect on shell weight and density in different housing systems, and eggs with the highest weight and density were obtained in the litter floor system from Hy-line Brown hens. The effect of breed on shell strength was only confirmed for litter rearing, in which eggs with the strongest shell were laid by Hy-line Brown hens. Studies by other authors, concerning the effect of breed on shell thickness, give varying results. Van den Brand et al. (2004) and Zita et al. (2009) demonstrated no effect of hen breed on shell thickness, while Hanusová et al. (2015), who studied the quality of eggs from Orávka and Rhode Island Red hens, concluded that the eggs differed in shell thickness by $11.55 \mu \mathrm{m}$. Tůmová et al. (2016) demonstrated the influence of genotype on shell weight as well as on the shell thickness and its density in studies carried out on eggs from both Lohmann and Czech hens. Both Kühn et al. (2014) and Hammershøj \& Steenfeldt (2015) also observed breed to have an influence on egg shell traits.

Our study showed that the housing system had no effect on albumen height $(\mathrm{P}>0.05)$, but it influenced Haugh units $(\mathrm{P}<0.05)$ In all the housing systems, breed had an effect on albumen height and Haugh units (Table 3). Samiullah et al. (2017) showed Haugh units to be lower for barn eggs compared to free-range eggs. Lordelo et al. (2017) demonstrated that the albumen from both barn and freerange eggs were characterized by similar Haugh units, but were lower than in egg albumen from organic farms. Küçükyılmaz et al. (2012) reported that albumen height in the eggs from white hens was not affected by the housing system, whereas in eggs from organically raised brown hens, albumen height and Haugh units were higher than under the conventional system.

The housing system had an effect on yolk weight, whereas the effect of hen genotype on this trait was not significant $(\mathrm{P}>0.05)$ (Table 3). The highest yolk weight in the barn system was characteristic of eggs from Hyline Brown hens. Also Rizzi and Marangon (2012) found the effect of breed on yolk size, with hens of Italian breeds producing heavier eggs than commercial hybrids, and white-feathered hens laying eggs with greater yolk compared to brown-feathered hens. Krawczyk (2009) reported lower yolk weight in the eggs from native hens compared to commercial hybrids. Van den Brand et al. (2004) concluded that quality traits of free-range eggs showed greater variation than quality traits of cage eggs for most of the measured parameters, and observed that it is more difficult to maintain the quality of free-range eggs throughout the egg production period. This is also confirmed by our study, in which most of the analysed egg traits showed higher variation in the free-range and organic systems compared to the litter floor system.

Neither the housing system nor the hen genotype had an effect on the incidence of blood spots in the eggs $(\mathrm{P}>0.05)$ (Table 3.) Similar results were obtained by Lordelo et al. (2017). whereas studies of Hidalgo et al. (2008) showed 
Sokołowicz, et al.

Table 3: Effect of housing system and hen's genotype on interior egg traits

\begin{tabular}{|c|c|c|c|c|c|c|c|c|}
\hline \multirow[t]{2}{*}{ Item } & \multirow[t]{2}{*}{ Housing system } & \multicolumn{3}{|c|}{ Genotype } & \multirow[t]{2}{*}{ SEM } & \multicolumn{3}{|c|}{ Effekt } \\
\hline & & $\mathrm{Z}-11$ & R-11 & Hy-line Brown & & $\mathbf{G}$ & $\mathrm{S}$ & GxS \\
\hline \multirow[t]{3}{*}{ Albumen height $(\mathrm{mm})$} & OLitter floor & $7.27^{a}$ & $7.49^{a b}$ & $8.04^{b}$ & 0.09 & * & NS & NS \\
\hline & Free range & $6.97^{\mathrm{aA}}$ & $7.11^{\mathrm{aA}}$ & $8.07^{\mathrm{bB}}$ & & & & \\
\hline & Organic & 7.74 & 7.08 & 7.99 & & & & \\
\hline \multirow[t]{3}{*}{ Haugh units (HU) } & Litter floor & ${ }^{x} 79.43^{\mathrm{aAB}}$ & $76.70^{\mathrm{aA}}$ & ${ }^{\mathrm{x}} 84.80^{\mathrm{bB}}$ & 0.71 & * & * & * \\
\hline & Free range & ${ }^{x \times} 75.33^{\mathrm{aA}}$ & $75.17^{\mathrm{aA}}$ & ${ }^{\mathrm{xy}} 90.63^{\mathrm{bB}}$ & & & & \\
\hline & Organic & ${ }^{\mathrm{y}} 88.87^{\mathrm{aA}}$ & $77.29^{\mathrm{bB}}$ & y88.29aA & & & & \\
\hline \multirow[t]{3}{*}{ Yolk weight (g) } & Litter floor & $17.66^{\mathrm{aA}}$ & $18.38^{\mathrm{bAB}}$ & $\mathrm{xx} 18.93^{\mathrm{bB}}$ & 0.10 & NS & * & NS \\
\hline & Free range & $17.06^{\mathrm{a}}$ & $17.80^{b}$ & ${ }^{y} \mathrm{Y} 18.00^{\mathrm{b}}$ & & & & \\
\hline & Organic & 17.91 & 17.63 & yY17.41 & & & & \\
\hline \multirow[t]{3}{*}{ Blood spots (\%) } & Litter floor & $\times \times 5.00^{a}$ & $25.00^{\mathrm{ab}}$ & $36.67^{b}$ & 3.16 & NS & NS & NS \\
\hline & Free range & ${ }^{x \times} 0.00^{a A}$ & $23.33^{\mathrm{bAB}}$ & $33.33^{\mathrm{bB}}$ & & & & \\
\hline & Organic & yY40.00 & 13.33 & 26.67 & & & & \\
\hline \multirow[t]{3}{*}{ Meat spots (\%) } & Litter floor & $0.00^{\mathrm{aA}}$ & $10.00^{\mathrm{ab} A B}$ & $30.00^{\mathrm{bB}}$ & 2.91 & * & NS & NS \\
\hline & Free range & $0.00^{\mathrm{aA}}$ & $33.33^{\mathrm{bB}}$ & $20.00^{\mathrm{abAB}}$ & & & & \\
\hline & Organic & $10.00^{\mathrm{a}}$ & $20.00^{\mathrm{ab}}$ & $46.67^{b}$ & & & & \\
\hline \multirow[t]{3}{*}{ Yolk colour (DSM) } & Litter floor & ${ }^{x} 6.55^{a A}$ & ${ }^{\mathrm{x}} \times 7.15^{\mathrm{bAB}}$ & ${ }^{\mathrm{x}} 7.67^{\mathrm{bB}}$ & 0.11 & NS & * & * \\
\hline & Free range & ${ }^{\mathrm{y}} 9.15^{\mathrm{aA}}$ & ${ }^{\mathrm{y}} 9.10^{\mathrm{aA}}$ & ${ }^{y Y} 8.43^{\mathrm{bB}}$ & & & & \\
\hline & Organic & $\mathrm{zz} 10.80$ & $\mathrm{zz} 10.27$ & zz10.33 & & & & \\
\hline
\end{tabular}

$\mathrm{G}$ - Genotyp S - Housing system, * significant $(\mathrm{P}<0.05)$; NS non significant $(\mathrm{P}>0.05)$; $a, b, \mathrm{c}-$ values in rows with different letters differ significantly $(\mathrm{P}<0.05)$; $A, B, C-$ values in rows with different letters differ significantly $(P<0.01) ; x, y, z$ - values in columns with different letters differ significantly $(P<0.05) ; X, Y$,

$Z$ - values in columns with different letters differ significantly $(P<0.01)$

a lower incidence of meat spots in eggs from free-range system compared with litter and organic systems.

The housing system had an effect on the yolk colour $(\mathrm{P}<0.05)$. Our study showed that egg yolk colour in hens of the studied breeds was more intense under the organic and free-range systems compared to the litter floor system. The more intensive yolk colour during the egg production period can be associated with access of hens to an outdoor run, in which the layers could ingest grass and herbs during the spring period (June). Horsted et al. (2006) and Hammershøj \& Johansen (2016) proved that plants eaten by hens on free range have a positive effect on yolk colour. Also Karadas et al. (2005) demonstrated that eggs from free-range hens have a higher yolk carotenoid content compared to the hens without outdoor access. In our study, yolk colour intensity of organic eggs was higher than for barn eggs. A study on the yolk colour of eggs from different housing systems, sold in Spain and Portugal, showed that alternative housing system eggs were paler and with more varied colour (Martínez-Alesón and Hamelin, 2014). Also in the study by Terčič et al. (2012), organically raised hens produced eggs with paler yolk colour than caged hens fed standard diet. Our different results, namely the more intensive yolk colour of free-range and organic eggs compared to barn eggs is probably due to the fact that in our study, hens in all housing systems received feed without pigments. In our study, eggs from organic hens were characterized by more intensive yolk colour, which may result from the free range in the organic farm being greater and more abundant in forage. Van Ruth et al. (2011) observed a different carotenoid profile for organic eggs compared to free-range and barn eggs, concluding that this is probably due to the use of synthetic carotenoids in the organic system.

Higher vitamin $\mathrm{A}$ and $\mathrm{E}$ content of eggs was characteristic of organic and free-range eggs compared to barn eggs (Table 4). According to Leeson (2007), for many vitamins there is a linear relationship between their content in feed and in egg yolk. In our study, eggs from free-range and organic hens had a higher vitamin A than eggs from the hens without outdoor access, which allows a conclusion that free-range hens ingested the carotenoids that had a beneficial effect on the vitamin A content of egg yolks. Thus, in the hen's body, part of $\beta$-carotene is transformed into vitamin A (Hencken, 1992). Meluzzi et al. (2000) report that increased alpha-tocopherol content of feed increases its content in yolk, whereas Bölükbașı et al. (2007) showed that vitamin $\mathrm{E}$ concentration increases linearly with its increasing level in the feed. The existence of a dependency between vitamin $\mathrm{E}$ content of feeds and in eggs was also demonstrated by Zang et al. (2011). Skrivan \& Englmaierová (2014), demonstrated higher contents of vitamins A and E in eggs from hens held with outdoor access.

One quality trait that has generated considerable interest among consumers is the cholesterol content of egg yolk. In our study, we found no effect of rearing system on the yolk cholesterol content of eggs from the experimental hens $(\mathrm{P}>0.05)$ (Table 4). The literature did not conclusively confirm the relationship between housing system and the 
Sokołowicz, et al.

Table 4: Effect of housing system and genotype on vitamin A and E and cholesterol content in egg yolks

\begin{tabular}{|c|c|c|c|c|c|c|c|c|}
\hline \multirow[t]{2}{*}{ Item } & \multirow[t]{2}{*}{ Housing system } & \multicolumn{3}{|c|}{ Genotype } & \multirow[t]{2}{*}{ SEM } & \multicolumn{3}{|c|}{ Effect } \\
\hline & & $\mathrm{Z}-11$ & R-11 & Hy-line Brown & & G & $\mathrm{s}$ & GxS \\
\hline \multirow[t]{3}{*}{ Vitamin A $(\mu \mathrm{g} / \mathrm{g})$} & Litter floor & $\times 5.06$ & 5.34 & $\times 5.14$ & 0.14 & NS & * & NS \\
\hline & Free range & '⿳6.86 & 6.16 & ${ }^{y} 6.01$ & & & & \\
\hline & Organic & ${ }^{y} 6.33^{\mathrm{aAB}}$ & $6.32^{\mathrm{aA}}$ & xy $5.67^{\text {bB }}$ & & & & \\
\hline \multirow[t]{3}{*}{ Vitamin $E(\mu \mathrm{g} / \mathrm{g})$} & Litter floor & $\times 62.37$ & 66.37 & $\times 68.52$ & 2.00 & NS & * & NS \\
\hline & Free range & xy 75.63 & 79.32 & xy 74.41 & & & & \\
\hline & Organic & y84.05 & 84.53 & y79.39 & & & & \\
\hline \multirow[t]{3}{*}{ Cholesterol (mg/g) } & Litter floor & 14.24 & 14.67 & 14.24 & 0.05 & NS & NS & NS \\
\hline & Free range & 14.24 & 14.55 & 14.38 & & & & \\
\hline & Organic & 14.22 & 14.92 & 14.68 & & & & \\
\hline
\end{tabular}

G - Genotyp S - Housing system, * significant $(P<0.05)$; NS non significant $(P>0.05)$; $a, b, c-$ values in rows with different letters differ

significantly $(P<0.05) ; A, B, C-$ values in rows with different letters differ significantly $(P<0.01) ; x, y, z-$ values in columns with different letters differ

significantly $(P<0.05) ; X, Y, Z$ - values in columns with different letters differ significantly $(P<0.01)$

egg yolk cholesterol content in hens. Küçükyılmaz et al. (2012) reported no effect of the housing system on egg yolk cholesterol content. Similarly, Dong et al. (2017) did not demonstrate differences in cholesterol content in the yolk of eggs from both free-range with or without outdoor access. In our study, the differences in egg yolk cholesterol levels between the studied breeds were not significant (Table 4.). Our results fail to confirm an earlier report (Krawczyk et al., 2011) in which egg yolk cholesterol content was significantly lower in the native Greenleg Partridge hens compared to the hens of other breeds. Rizzi and Chiericato (2010) and Rizzi and Marangon (2012), who investigated eggs from Hy-line Brown, Hy-line White and two local breeds of hens (Ermelluinata di Rovigo and Robusta Maculata) also showed that genotype has an effect on the cholesterol level. In both studies, the cholesterol level was higher in the yolks of eggs from local breeds of hens than from commercial hybrids. Wang et al. (2009) noted that Araucana hens lay eggs with lower cholesterol content compared to commercial layers. In turn, Millet et al. (2006) and Gultemirian et al. (2009) found higher cholesterol content in the yolk of eggs from Araucana hens compared to eggs from the commercial Isa Brown and Lohmann hens.

The fatty acid profile of egg yolks was characterized by a relatively low $(38.7-40.9 \%)$ proportion of saturated fatty acids (SFA), which was paralleled by a high (45.5-52.6\%) proportion of mono- (MUFA) and polyunsaturated fatty acids (8.7-16.5\%) (PUFA) (Table 5). The housing system had no effect on the proportion of SFA and unsaturated fatty acids (UFA) in the egg yolks ( $\mathrm{P}>0.05)$. For MUFA and PUFA, the impact of the rearing system was statistically significant $(\mathrm{P}<0.05)$. The highest level of MUFA and the lowest level of PUFA were characteristic of egg yolks from free-range hens $(P<0.05)$. The percentage of PUFA $n-6$ was highest in egg yolks from the litter system $(\mathrm{P}<0.05)$.

The current studies have confirmed the influence of housing systems on the content of fatty-acids, PUFA n-6 and PUFA, n-3 in egg yolks. Studies by Lordelo et al. (2017) also demonstrated that the content of PUFA n-6 fatty-acids in from free-range and organic systems was lower than in eggs from litter floor system. Outdoor access, both in the free-range and in the organic systems had a beneficial effect on the proportion of nutritionally important unsaturated fatty acids as well as the PUFA $n-6 / n-3$ ratio. The higher UFA content of free-range and organic eggs can be associated with the outdoor access, because the factors increasing the proportion of PUFA n-3 in egg yolk include forage, fresh vegetables and invertebrates Campos et al. (2016). The results obtained correspond with the findings of other authors. Anderson (2011), who analysed the quality of eggs from hens of the same breed that received the same diet and were raised in free-range and barn systems, concluded that barn eggs contained more PUFA and MUFA. Simčič et al. (2011) also indicated the existence of correlation between the farming system and the profile of fatty acids in the yolk of eggs from the autochthonous Styrian (Slovenia). Hidalgo et al. (2008) showed no differences in the composition of fatty acids between cage, free-range, barn, and organic eggs. In the study by Terčič et al. (2012), organic eggs compared to cage eggs were characterized by a higher content of $n-3$ fatty acids, including alpha-linolenic (18:3, n-3) and docosapentaenoic acids (22:5, n-3). In the same study, the $\mathrm{n}-6 / \mathrm{n}-3$ fatty acids ratio was more favourable in eggs from the organic system (5.93:1) compared to the cage system (9.55:1). In the study by Hidalgo et al. (2013), eggs from organic hens had a lower MUFA and a higher PUFA content, which they believe reflects a different fatty acid profile of the feed ingested on free range in the form of PUFA-rich grasses. Krawczyk et al. (2011) showed a beneficial effect of outdoor access on increasing the proportion of UFA in the yolk of eggs from Greenleg Partridge and Yellowleg Partridge hens. The optimal n-6/n-3 fatty acids ratio ranges from 4to 10 (Simopoulos, 2000). In our study, this $n-6 / n-3$ ratio was observed in free-range and organic eggs, which points to the positive effect of outdoor access on this trait. 
Table 5: Effect of housing system and genotype on SFA and UFA percentage in egg yolks

\begin{tabular}{|c|c|c|c|c|c|c|c|c|}
\hline \multirow[t]{2}{*}{ Item } & \multirow[t]{2}{*}{ Housing system } & \multicolumn{3}{|c|}{ Genotype } & \multirow[t]{2}{*}{ SEM } & \multicolumn{3}{|c|}{ Effect } \\
\hline & & $Z-11$ & R-11 & Hy-line Brown & & $\mathbf{G}$ & $\mathrm{s}$ & GxS \\
\hline \multirow[t]{3}{*}{ SFA } & Litter floor & 39.38 & xy 40.07 & $\times 40.87$ & 0.21 & NS & NS & * \\
\hline & Free range & $40.42^{\mathrm{a}}$ & $\times 38.90^{\mathrm{a}}$ & y38.71 & & & & \\
\hline & Organic & $39.31^{\mathrm{ab}}$ & y $40.58^{a}$ & У38.98 & & & & \\
\hline \multirow[t]{3}{*}{ UFA } & Litter floor & 60.63 & xy 59.95 & $\times 58.93$ & 0.21 & NS & NS & * \\
\hline & Free range & $59.58^{a}$ & ${ }^{x} 61.10^{b}$ & ${ }^{\mathrm{y}} 61.29^{\mathrm{b}}$ & & & & \\
\hline & Organic & $60.69^{\mathrm{ab}}$ & у $59.42^{\mathrm{a}}$ & ${ }^{\mathrm{y}} 61.02^{\mathrm{b}}$ & & & & \\
\hline \multirow[t]{3}{*}{ MUFA } & Litter floor & xXY46.60 & 45.57 & xx47.23 & 0.42 & * & * & NS \\
\hline & Free range & ${ }^{\mathrm{y} x} 48.86^{\mathrm{a}}$ & $48.66^{a}$ & ${ }^{y} 52.59^{b}$ & & & & \\
\hline & Organic & ${ }^{\times Y} 45.71^{\mathrm{aA}}$ & $47.25^{\mathrm{aAB}}$ & ${ }^{z \times} 49.49^{\mathrm{bB}}$ & & & & \\
\hline \multirow[t]{3}{*}{ PUFA } & Litter floor & ${ }^{x x} 16.04^{\mathrm{aA}}$ & ${ }^{x x} 16.54^{a A}$ & $\mathrm{xx} 13.20^{\mathrm{bB}}$ & 0.45 & * & * & * \\
\hline & Free range & ${ }^{\mathrm{yY}} 10.72^{\mathrm{ab}}$ & ${ }^{\mathrm{y}} 11.18^{\mathrm{a}}$ & $y^{y} 8.70^{b}$ & & & & \\
\hline & Organic & $\mathrm{xx} 14.98^{\mathrm{aA}}$ & ${ }^{\mathrm{y}} 11.90^{\mathrm{bB}}$ & $\mathrm{zx} 11.53^{\mathrm{bB}}$ & & & & \\
\hline \multirow[t]{3}{*}{ PUFA n-6 } & Litter floor & $x \times 12.77^{\mathrm{aA}}$ & ${ }^{x x} 13.09^{a A}$ & $\mathrm{xx} 10.46^{\mathrm{bB}}$ & 0.36 & * & * & NS \\
\hline & Free range & ${ }^{y} 8.78^{a}$ & ${ }^{\mathrm{y}} 9.62^{\mathrm{a}}$ & ${ }^{y} 6.58^{b}$ & & & & \\
\hline & Organic & $x \times 12.22^{a}$ & ${ }^{\mathrm{yXY}} 10.82^{\mathrm{ab}}$ & $\times \times 9.91^{b}$ & & & & \\
\hline \multirow[t]{3}{*}{ PUFA n-3 } & Litter floor & $x \mathrm{x} 1.04^{\mathrm{aA}}$ & ${ }^{\mathrm{x}} 1.06^{\mathrm{aA}}$ & ${ }^{\mathrm{x} x} 0.87^{\mathrm{bB}}$ & 0.07 & * & * & * \\
\hline & Free range & $\mathrm{yY}_{1.74^{\mathrm{aA}}}$ & $\mathrm{yx} 1.34^{\mathrm{bB}}$ & $\mathrm{yY}^{\mathrm{Y}} 1.88^{\mathrm{aA}}$ & & & & \\
\hline & Organic & ${ }^{\mathrm{zY}} 1.98^{\mathrm{aA}}$ & ${ }^{x y} 0.89^{\mathrm{bB}}$ & $\mathrm{zz} 1.38^{\mathrm{cC}}$ & & & & \\
\hline \multirow[t]{3}{*}{ PUFA n-6/3 } & Litter floor & $x x_{12.26}$ & $x x_{12.38}$ & $\mathrm{xx} 12.11$ & 0.58 & * & * & * \\
\hline & Free range & ${ }^{\mathrm{Y}} 5.06^{\mathrm{aA}}$ & ${ }^{\mathrm{y}} 7.22^{\mathrm{bB}}$ & ${ }^{\mathrm{y}} 3.49^{\mathrm{cc}}$ & & & & \\
\hline & Organic & ${ }^{\mathrm{ZY}} 6.20^{\mathrm{aA}}$ & ${ }^{x X} 12.31^{\mathrm{bB}}$ & $\mathrm{zz} 7.26^{\mathrm{aA}}$ & & & & \\
\hline
\end{tabular}

$G$ - Genotype $S$ - Housing system, * significant $(P<0.05)$; NS non significant $(P>0.05)$; $a, b, c-$ values in rows with different letters differ significantly $(P<0.05)$ $A, B, C-$ values in rows with different letters differ significantly $(P<0.01) ; x, y, z$ - values in columns with different letters differ significantly $(P<0.05)$; $X, Y$, $Z$ - values in columns with different letters differ significantly $(P<0.01)$; SFA - saturated fatty acids; UFA - unsaturated fatty acids; MUFA - monounsaturated fatty acids; PUFA - polyunsaturated fatty acids

\section{CONCLUSIONS}

The research findings on the impact of types of alternative breeding and the hen's genotype on eggs quality features may be of significant importance for both producers and consumers. Eggs with the highest weight were laid by commercial hens, and the type of alternative housing system had no significant effect on this trait. Shell colour intensity depends on the breed of hen, whereas the housing system has no significant effect on this trait. No effect of the housing system and genotype on egg yolk cholesterol content was observed. Eggs from hens held in free-range as well as ecological breeding are characterized by a more favourable, for humans, ratio of PUFA $6 / 3$, higher vitamins $\mathrm{A}$ and $\mathrm{E}$ content, and also have more intensive yolk colour, which meets the expectations of consumers, that are willing to pay more for eggs from free-range or ecological farms, assuming that such systems do not only improve the welfare of hens but also leads to improved quality of the eggs.

\section{AUTHORS' CONTRIBUTIONS}

The study (experimental) design was achieved by S. Z, the actual research organized by K.J., while D. M. tabulated the results and conducted the statistical analyses. The findings were analysed and interpreted by all three authors. Z.S. and
M.D. wrote the manuscript which was read and approved by all authors.

\section{REFERENCES}

Anderson, K.E. 2011. Comparison of fatty acid, cholesterol, and vitamin $A$ and $E$ composition in eggs from hens housed in conventional cage and range production facilities. Poultry Sci., 90: 1600-1608.

Bölükbaşı, C. Ş., K. M. Erhan, S. M. Keleş and R. Koçyiğit. 2007. Effect of dietary vitamin $E$ and the performance, plasma and egg yolk vitamin $E$ levels and lipid oxidation of egg in heat stressed layers. J. Appl. Biol. Sci., 1(3): 19-23.

Campos, A. M., Ricardo, F., Alves, E., Reis, A., Couto, D., Domingues, P., Domingues, M. R.M. 2016. Lipidomic investigation of eggs'yolk: Changes in lipid profile of eggs from different conditions. Food Res. Int. 89: 177-185.

Council Directive 1999/74/EC. 1999. Laying down minimum standards for the protection of laying hens. Off. J. 203: 53-57.

Dalle Zotte, A., A. Sartori and V. Bordesan. 2013. Physical Egg Quality from Organic Versus Conventional Laying Hens. Proc. XV Eur. Symp. on the Quality of Eggs and Egg Products, Bergamo. Bergamo, 15-19 September 2013.

Dong, X. Y., Yin, Z. Z., Ma, Y. Z, Cao, H. Y. and Dong D. J. 2017. Effects of rearing systems on laying performance, egg quality, and serum biochemistry of Xianju chickens in summer. Poult. Sci. 96(5): 1485-1491.

Englmaierová, N., E. Tunova, V. Charvátova and M. Skrivan. 2014. Effects of laying hens housing system on laying performance, egg quality characteristics and egg microbial contamination. Czech J. Anim. Sci., 8: 345-352. 
Ferrante, V., S. Lolli, G. Vezzoli and L. Guidobono Cavalchini. 2009. Effects of two different rearing systems (organic and barn) on production performance, animal welfare traits and egg quality characteristics in laying hens. Ital. J. Anim. Sci. 8: 165-174.

Folch, J., M. Lee and G.H. Sloan-Stanley. 1957. A simple method for the isolation and purification of total lipids from animal tissues. J. Biol. Chem., 226: 497-509.

Gąsior, R. and M. Pietras. 2013. Validation of a method for determining cholesterol in egg yolks. Ann. Anim. Sci. 13(1): 143-153.

Gultemirian, M., L. De, S. Van Nieuwenhove, A. Pèrez Chaia and M. C. Apella. 2009. Physical and chemical characterization of egg from Araucana hens of free range fed in Argentina. J. Argent. Chem. Soc. 97(2): 19-30.

Hammershøj, M. and S. Steenfeldt. 2015. Organic egg production. II: The quality of organic eggs is influenced by hen genotype, diet and forage material analyzed by physical parameters, functional properties and sensory evaluation. Anim Feed Sci. Tech. 208: 182-197.

Hammershøj, M. and Johansen, N. F. 2016. Review: The effect of grass and herbs in organic egg production on egg fatty acid composition, egg yolk colour and sensory properties. Livestock Sci. 194: 37-43.

Hanusová, E., E. Hrnčár, A. Hanus and M. Oravcová. 2015. Effect of breed on some parameters of egg quality in laying hens. Acta Fytotechn. Zoot. 18(1): 20-24.

Hencken, H. 1992. Chemical and physiological behavior of feed carotenoids and their effects on pigmentation. Poult. Sci. 71: 711-717.

Hidalgo, A., M. Rossi, S. Clerici and S. Ratti. 2008. A market study on the quality characteristics of egg from different housing systems. Food Chem. 106: 1031-1038.

Hidalgo, A., S. Ratti and M. Rossi. 2013. Lipid profile in feed and egg yolk from barn, cage, and organic systems at different hen ages. Egg Meat Symposia, Bergamo. World Poult. Sci. J. 69: 1-5.

Holt, P. S., R. H. Davies, J. Dewulf, R. K. Gast, J. K. Huwe, D. R. Jones, D. Waltman and K. R. Willian. 2011. The impact of different housing systems on egg safety and quality. Poult. Sci. 90: 251-262.

Horsted, K., M. Hammershøj and J. E. Hermansen. 2006. Shortterm effects on productivity and egg quality in nutrient-restricted versus non-restricted organic layers with access to different forage crops. Acta Agric. Scand. A Anim. Sci. 56: 42-54.

Jones, D. R. and K. Anderson. 2013. Housing system and laying hen strain impacts on egg microbiology. Poult. Sci. 92(8): 2221-2225.

Karadas, F., N. A. R. Wood, P. F. Surai and N. H. C. Sparks. 2005. Tissue-specific distribution of carotenoids and vitamin $E$ in tissues of newly hatched chicks from various avian species. Comp. Biochem. Physiol A. Mol. Integr. Physiol. 140: 506-511.

Krawczyk, J. 2009. Effect of layer age and egg production level on changes in quality traits of eggs from hens of conservation breeds and commercial hybrids. Ann. Anim. Sci. 9(2): 185-193.

Krawczyk, J., Sokołowicz Z. and B. Szymczyk. 2011. Effect of housing system on cholesterol, vitamin and fatty acid content of yolk and physical characteristics of eggs from Polish native hens. Arch. Geflügelk. 75(3): 151-157.

Küçükyılmaz, K., M. Bozkurt, E. Nur Herken and M. Çınar. 2012. Effects of rearing systems on performance, egg characteristics and immune response in two layer hen genotype. Asian-Aust. J. Anim. Sci. 25(4): 559-568.

Kühn, J., A. Schutkowski, H. Kluge, F. Hirche and G. Stangl. 2014. Free-range farming: A natural alternative to produce vitamin D-enriched eggs. Nutrition. 30: 481-484.
Leeson, S. 2007. Vitamin requirements: Is there basis for re-evaluating dietary specifications? World Poult. Sci. J. 63: 255-266.

Lordelo, M., E. Fernandes, E., R. J. B. Bessa and S. P. Alves. 2017. Quality of eggs from different laying hen production systems, from indigenous breeds and specialty eggs. Poult Sci. 96(5): 1485-1491.

Martínez-Alesón, R. and C. Hamelin. 2014. Estudio de Huevos de Gallina Adquiridos en Supermercados de Distintas Regiones en la Peninsula Ibérica: Etiquetado, Precio y Color de la Yema. Proc. LI Scientific Symposium WPSA's Spanish Branch, Valencia. Available from: http://www.wpsaaeca.com.

Meluzzi, A., F. Sirri, G. Manfreda, N. Tallarico and A. Franchini. 2000. Effects of dietary vitamin $E$ on the quality of table eggs enriched witch n-3 ling-chain fatty acids. Poult. Sci. 79: 539-545.

Mertens, F., B. Bamelis, B. Kemps, E. Kamers, B. Verhoelst, M. De Ketelaere, E. Bain Decuypere and J. De Baerdemaeker. 2006. Monitoring of eggshell breakage and egg shell strength in different production chains of consumption eggs. Poult. Sci. 85(9): 1670-1677.

Millet, S., K. De Ceulaer, M. Van Paemel, K. Raes, S. De Smet and G. P. J. Janssens. 2006. Lipid profile in egg of Araucana hens compared with Lohmann Selected Leghorn and Isa Brown hens given diets with different fat sources. Brit. Poult. Sci. 47(3): 294-300.

Nedup, D. and K. Phurba. 2014. Evaluation of egg quality parameters in Bhutanese indigenous chickens vis-a-vis exotic chicken. Indian J. Anim. Sci. 84(8): 884-890.

Pavlovski, Z., S. Hopic and M. Lukic. 2001. Housing systems for layers and egg quality. Anim. Biotechnol. Husbandry. 17: 197-201.

Rizzi, C. and A. Marangon. 2012. Quality of organic eggs of hybrid and Italian breed hens. Poult. Sci. 91: 2330-2340.

Rizzi, C. and G. M. Chiericato. 2010. Chemical composition of meat and egg yolk of hybrid and Italian breed hens reared using an organic production system. Poult. Sci. 89: 1239-1251.

Samiullah, R. J. R. and K. K. Chousalkar. 2014. Effect of production system and flock age on egg quality and total bacterial load in commercial laying hens. J. Appl. Poult. Res. 23(1): 59-70.

Samiullah, S., A. S. Omar, J. Roberts and K. Chousalkar. 2017. Effect of production system and flock age on eggshell and egg internal quality measurements. Poult Sci. 96(1): 246-258.

Simčič, M., V. Stibilj, A. and Holcman. 2011. Fatty acid composition of eggs produced by the Slovenian autochthonous Styrian hen. Food Chem. 125(3): 873-877.

Simopoulos, A. P. 2000. Symposium: Role of poultry products in enriching the human diet with n-3 PUFA. Poult. Sci. 79: 961-970.

Skrivan, M. and Englmaierová, M. 2014. The deposition of carotenoids and tocopherol in hen eggs produced under a combination of sequential feeding and grazing. Anim. Feed Sci. Technol. 190: 79-86.

Terčič, D., B. Žlender and A. Holcman. 2012. External, internal and sensory qualities of table eggs as influenced by two different production system. Agro Knowl. J. Univ. Banjaluka Facul. Agric. 13: $555-562$.

Tůmová, E., J. Vlčková, V. Charvátová, O. Drábek, V. Tejnecký, M. Ketta and D. Chodová. 2016. Interactions of genotype, housing and dietary calcium in layer performance, eggshell quality and tibia characteristics. SA Anim Sci. 46(3): 285-293.

Van Den Brand, H., H. K. Parmentier and A. B. Kemp. 2004. Effects of housing system (outdoor vs cages) and age of laying hens on egg characteristics. Brit. Poult. Sci. 45(6): 745-752.

Van Ruth, S., M. Alewijn, K. Rogers, E. Newton-Smith, N. Tena, M. Bollen. and A. Koot. 2011. Authentication of organic and conventional eggs by carotenoid profiling. Food Chem. 126: 1299-1305. 
Wang, X. L., J. X. Zheng, Z. H. Ning, L. J. Qu, G. Y. Xu and N. Yang. 2009. Laying performance and egg quality of blue-shelled layers as affected by different housing systems. Poult. Sci. 88: 14851492.

Yılmaz Dikmen, B., A. İpek, Ü. Şahan, A. Sözcü and S.C. Baycan. 2017. Impact of different housing systems and age of layers on egg quality characteristics. Turk. J. Vet. Anim. Sci. 41(1): 77-84.

Yılmaz Dikmen, B., A. İpek, Ü. Şahan, M. Petek and A. Sözcü. 2016. The egg production and welfare of laying hens kept in different housings ystems (conventional, enriched cage, and free range). Poult. Sci. 95(7): 1564-1572.

Zang, H., K. Zhang, X. Ding, S. Bai, J. Hernandez. and B. Yao. 2011. Effects of different dietary vitamin combinations on the egg quality and vitamin deposition in the whole Egg of laying hens. Rev Bras Cienc Avic. 13: 189-196.

Zita, L., E. Tumova and L. Stolc. 2009. Effects of genotype, age and their interaction on egg quality in brown-egg laying hens. Acta Vet. Brno. 78: 85-91. 